\title{
Measuring Consumer Engagement in the Brain to Online Interactive Shopping Environments
}

Link to publication record in Manchester Research Explorer

\section{Citation for published version (APA):}

Dulabh, M., Casson, A., Vazquez, D., \& Ryding, D. (2017). Measuring Consumer Engagement in the Brain to Online Interactive Shopping Environments. In T. Jung, \& M. Claudia tom Dieck (Eds.), Augmented Reality and Virtual Reality- Empowering Human, Place and Business. (1 ed., pp. 145-168). Springer Nature.

\section{Published in:}

Augmented Reality and Virtual Reality- Empowering Human, Place and Business.

\section{Citing this paper}

Please note that where the full-text provided on Manchester Research Explorer is the Author Accepted Manuscript or Proof version this may differ from the final Published version. If citing, it is advised that you check and use the publisher's definitive version.

\section{General rights}

Copyright and moral rights for the publications made accessible in the Research Explorer are retained by the authors and/or other copyright owners and it is a condition of accessing publications that users recognise and abide by the legal requirements associated with these rights.

\section{Takedown policy}

If you believe that this document breaches copyright please refer to the University of Manchester's Takedown Procedures [http://man.ac.uk/04Y6Bo] or contact uml.scholarlycommunications@manchester.ac.uk providing relevant details, so we can investigate your claim.

\section{OPEN ACCESS}




\title{
Measuring Consumer Engagement in the Brain to Online Interactive Shopping Environments
}

\author{
Meera Dulabh, \\ Alex Casson, \\ Delia Vazquez, \\ Daniella Ryding \\ Department of Design, Fashion \& Business and Electrical Signal Processing \\ University of Manchester, United Kingdom \\ \{meera.dulabh\}\{ alex.casson $\}\{$ delia.vazquez $\}$ \{ daniella.ryding $\}$ \\ @manchester.ac.uk
}

\begin{abstract}
Online shopping environments are becoming more interactive as technology advances. As a result, it is necessary to explore marketing theories and neuro scientific explanations to why this is the case. A reviewed approach of consumer engagement to online interactive shopping environments is considered in this chapter. The online interactive elements of traditional fashion websites that are considered includes; social media, browsing and videos. Measurements of consumer engagement are reviewed via marketing consumer engagement theories (CE) and a cognitive neuroscience technique using an Electroencephalogram (EEG) (A non-invasive procedure measuring the brain's electrical activity). ASOS.com, the U.K. top fashion online pure player, is used as a preliminary research study, the results demonstrate that engagement is significantly different in social media, video and browsing tasks, browsing for jackets elicited more engagement. Originality of this research stems from the novel way to look at engagement and the ability to combine traditional and non-traditional marketing methods thus addressing emerging fields of the future such as virtual shopping.
\end{abstract}

Keywords: Online Interactivity, Consumer Engagement, EEG.

\section{Introduction}

Retail consumers are increasingly browsing and purchasing fashion items online. Store based retailers have prioritised internet retailing as a growth channel to which $90 \%$ of store based retailers in the UK have transactional websites (Euromonitor 2011).In the consumer market of 2015, total online sales of fashion products were $£ 42.5$ billion (Inc VAT) (Mintel 2016a). These consumers tend to shop on a computer (89\%) or smartphone (41\%) (Mintel 2016a). A majority of retailers are becoming internet only specialists with no physical store presence also known as pure-play internet retailers (Euro Monitor International 2011). A leading UK fashion pureplay retailer is that of ASOS.com who have brought in a revenue of $£ 7 \mathrm{M}$ in 2016 (Statista 2017) and consists of 8 million consumers in over 200 countries (Mintel 2014). In fact Snap Chat (a user generated social media channel) is being constantly used by ASOS as they post from it several times per week for young consumers aged 16-24 (Mintel 
2016b). Those that use these channels are millennials who are the keenest shoppers in this generation as most use six or more retailers per year to shop in online and in store (52\%) (Mintel 2016b). This goes to show that "Kids are getting older younger" with the current technological age in 2017 being generation Z born in the years 1991-2002 (Euromonitor International 2014). With that $70 \%$ of these shoppers are females (Skorupa 2012).

User Generated trends in social media: Twitter, Whatsapp, Facebook, Snapchat, Instagram and blogs evidences the current succession in web 3.0 (social, semantic, sentient and mobile web), progression to web 4.0 (integration of intelligent systems) and an end goal to create a Virtual Reality (VR) metaverse (everything 2D in web 1.0, 2.0 ,3.0 and 4.0 will be streamlined in 3D via VR)(KPMG2017). That being said, Virtual Reality and Augmented Reality (AR) projects which are forecasted to be used in the future with $£ 650 \mathrm{M}$ worth of hardware sales in 2016, currently have a high commercial focus on video games (Mintel 2016a, Deloitte Global 2017). A recent study showed that $58 \%$ of digital consumers think that shopping with technology would be more fun with $30 \%$ of the sample forecasting fitting rooms with interactive mirrors for the future and only 10\% forecasting VR shopping for the future (Mintel 2016b). An example of this would be the augmented reality app Pokemon Go which included Pokestops in retailer New Look likewise North Face used virtual reality for outdoor activities to promote their outdoor gear (Mintel 2016b). Due to the demand in consumer expenditure online in particular, consumer testing via biometric methods in both the online retail and VR domains is necessary as most research currently assessing consumer behaviour comes from surveys (Klienschmit et al., 2012).

For retailers to keep up with changing demands of the consumer and technology, it is necessary to investigate what constitutes as an interactive in order to sustain a competitive advantage. With this in mind the chapter is structured with a mentioning of online interactive environments with a focus on videos, social media and browsing content of websites. Once this is reviewed, measuring consumer behaviour to these interactive environments is considered. Engagement is the behaviour that has been chosen to be measured due to the strong support in marketing and neuroscience journals evidenced in sections 3 and 4.Finally in section 5 all of this is put together in a preliminary study using these three interactive environments (from ASOS.com) and measuring electrical brain responses to this stimuli. Its further suggested that this technique can be used in the newly emerging platform of virtual reality shopping.

\section{Online Interactivity}

\subsection{Introduction}

As interactive environments have evolved with time, an extended breadth of choice for the consumer has emerged in the form of desktops, laptops, mobile apps, apple watches or a combination of all of these which leads to the question, do consumers want online interactive environments? Only if the interactivity pays off (Steckel et al., 2005). The fact that we are unable to touch and see physical features of products online gives us many choices of product to choose from. Having all this of choice is desirable, but, consumers have limited cognitive resources and may be unable to 
process this abundance of information (Habul \& Trifts 2000). Therefore, interactive decision aids can help combat this problem to which consumers can make better decisions with less effort (Habul \& Trifts 2000). Benefits to online interactivity includes having more access to information, customisation of product and content, and availability of tools to help the information acquisition process (Steckel et al., 2005, Haubul \& Trifts 2000) and includes four features; reciprocity, responsiveness, nonverbal information and speed of response (Yoo et al., 2015). Online interactivity is influenced by web atmospherics constituting to the conscious designing of web environments to create positive reactions in consumers (Daily 2004, Manganari et al., 2008) and influences users engagement with the website by expanding their perceptual bandwidth such as psychological arousal on cognitive functioning (Kahnerman 1973, Xu \& Sundar 2014). Manganari et al.,, 2009) devise an "Online Store Environment Presentation Framework" in which they split their research into four components; virtual layout and design, virtual atmospherics, virtual theatrics and virtual social presence. The rest of this section follows this structure to which virtual social presence, virtual theatrics and virtual atmospherics are explained corresponding to relevant theories on the topic. Then multi sensory and virtual reality environments are reviewed.

\subsection{Virtual Social Presence}

Virtual social presence is a way that consumers can communicate with friends, family or the general public when online. Common themes of this include electronic word of mouth and virtual communities (Manganari et al., 2009). Morandin (2013) makes sense of virtual communities by expressing it as "A way in which consumers find meaning in their lives through joint experience with a brand with friends in a brand community”. Virtual communities enable members to post articles, reviews and product recommendations with feedback from other members (Gearhart and Zhang 2014). Product recommendations through virtual communities allows the provision of consumer trust (Hsaio et al., 2010). Websites of "Facebook.com" and "Twitter.com" provide a free public forum in which users can connect with friends and share information such as blogs, videos, photos, links and audio files.

Electronic Word of Mouth (e-WOM) includes any positive or negative statement made by consumers about a product or company which is made available to a mass community via the internet (Henning-Thurau et al., 2004), taking the form of discussion forums, text-based comments, video reviews, product reviews and social networking sites (SNS) (King et al 2014, Yoo et al., 2015). Compared to word of mouth (WOM), e-WOM takes place in computer mediated environments, whereas WOM occurs in face-face communication and does not contain this electronic element (Kin et al., 2014). eWOM systems are very influential, in fact, it is reported that $61 \%$ of consumers check online forums, consumer blogs and other sources for online customer reviews before they purchase products, simply because consumers trust consumer produced information (Yoo et al., 2015). However the lack of faceface in e-WOM interaction raises concern in that anonymity encourages unethical behaviour (Steckel et al 2005, Kiesler and Sproull 1992). Negative comments online otherwise known as negative word of mouth (NWOM) has a stronger impact on a consumers judgement, consumers trust and purchase intention compared to a website 
with positive comments, in females this effect is higher than males (Zhang et al., 2014, Yoo et al., 2015).

\subsection{Virtual Theatrics}

Virtual theatrics is a way in which retailers make their brand look like a 'theatre' through the use of images, video's, graphics and animation (Managari et al., 2008). Fiore and Kelly (2007) demonstrate how a demo video is striking and engaging compared to a static image. Visual merchandising incorporates images, music, products, colour and animation which in turn influences whether or not a customer will enter a store or a website (Ha et al., 2007).

Pure-play retailers such as ASOS.com have catwalk videos to present their product as they do not have a physical store presence. However, Kawaf \& Tagg (2017) report that the novelty of catwalk videos is warring off as consumers are wanting content that is 'closer to real life'. That being said, mall haul videos (vlogs); short videos where influential individuals promote fashion products and express opinion is video content 'close to real life'. eWOM has become very influential in shaping consumer's attitudes and decisions especially from vlogs as it satisfies social and self monitoring needs (Harnish \& Bridges 2016). This demonstrates how videos are becoming a form of social media.

\subsection{Virtual Atmospherics}

The term atmospherics is used in academic fields to represent "the design of shopping environments to provoke emotional effects in the buyer that enhance his purchase intention" (Kotler, 1973, p. 50). Navigation systems are links on a website that enables the user to find information through links to other pages, search facilities, directories or sitemaps. (Nielsen 1996). Webster and Ahuja (2006) demonstrate how some websites have failed in aiding navigational support as they get disorientated. Kluge et al., (2013) distinguished differences between a conventional online shopping homepage design with luxury shopping homepages. According to them, homepages are important as they are the first point of contact for users to which their initial impression is formed influencing their decision making process of whether or not to continue using the website. Luxury homepages differ to that of conventional homepages as they incorporate financial, functional, individual and social dimensions all entwined to represent the multi-sensory experience online. Websites that use an unstructured design, monotonous colours, or messy presentation of products can lead consumers to feel confused and angry (Koo \& Ju 2010, Okonkwo 2010).

\subsection{Multi-sensory Shopping Experiences}

Fiore and Kelly (2007) implement the use of sound as an atmospheric cue operating online. They found that larger organisations tend to integrate sound into their websites as it ignites memory of the interface rather than the visual representation of a physical store. Gorn et al., (2004) found for each dimension of colour, cool colours tended to relax consumers more, when an expensive item was presented in front of a cool background, this increased the likelihood of purchasing the product. Touch in the context of shopping can be defined as any physical contact between a shopper and a product. Touching the product enables the consumer to assess the products properties and the more frequent the touch, the more engaged the consumer is with that product 
(Peck and Childers 2003, Zhang et al., 2014).Shopper density refers to the physical density in a given space (Zhang et al., 2014). Theories on over crowding report that confined spaces with a high frequency of shoppers tend to provoke a negative emotional response. The widely accepted idea is that perceived crowding negatively affects shopping satisfaction as it leads to invasion of personal space (Metha 2013, Zhang et al., 2014). Wade et al., (2012) suggested that shoppers need room when shopping to prevent 'butt brushing' and to allow them to navigate their way around the shop freely.

\subsection{Virtual Shopping Environments}

Augmented, virtual and mixed reality are becoming in demand as the technology progresses and augmented reality has been researched academically with regards to consumer engagement (Huang \& Huang 2017). In Virtual Reality (VR) and traditional online shopping, males are more focused on practical characteristics with rational thinking whereas females are more focused on the entertainment and emotional catharsis (Zhao et al., 2017).

Virtual avatars which are computer created beings also known as second life can also be described using virtual liminoid theory which suggests with the use of augmented reality technology (ARIT), consumers transition from a physical context through to virtual context via clothes fitting in AR. This state from real to virtual self triggers a psychological state which promotes the decoration of an avatar and this state is a form of engagement described as immersion or flow (Huang \& Huang 2017, Jung \& Pavlowski 2014). Haptic imagery being a 3D visiotactile stimuli has been used with AR to stimulate a real sense of touch (Huang \& Huang 2017). Neuro-imaging studies using fMRI scans reveals in real life humans who create versions of themselves in AR or use virtually created clothes on themselves feel as though that is their real body in AR otherwise known as a sense of body ownership (Kelley et al., 2002, Kircher et al., 2000, Turk et al 1991). Thus, the concept of embodied cognition to which a sense of 'real to virtual self' is created of AR online shopping is through the body's online experience and self (Zhao et al., 2017).In fact, self related interactive information is a trigger for the brain area responsible for the perception of self (Bargh 1982, Huang \& Huang 2017).

When comparing interfaces, it was found that a 2D interface enabled consumers to spend longer searching and engaging with it compared to a 3D interface, as a 2D interface is highly interactive (Mazursky and Vinitzky 2005). However, one would think that a 3D interface is more interactive due to novelty. To test this, some websites are introducing 3D interfaces as a virtual atmospheric cue for consumers. Wu et al., (2013) Creates a 3D mock shop in virtual reality and found that those who shopped in a store based on trends of fashion spent more money than those that shopped in the colour/visual stores. Those who shopped in the colour stores experienced more pleasure/ purchase intention than those who shopped in the trendlead stores. Immersive 3D store environments are seen to simulate products more closely than a 2D virtual store environment due to a richer presentation of the product and a greater level of interactivity (Jiang \& Benbasat 2007). However, the threat is that consumers who are more functional when shopping will perceive vivid presentation to be less useful as content will be deemed as ambiguous (Hoch \& 
Deighton 1989). Consumers who shop for fun rather than function are less likely to discriminate against ambiguous information (Gilovich et al., 2015). Wu et al (2015) suggest that in a 3D virtual environment retailers shouldn't focus on designing a merely functional environment in 3D but a clear environment focusing on lifestyle rather than merchandise. Virtual shopping tasks have also been performed to help those with disabilities. Negut et al., (2016) found that stroke patients did not complete their task efficiently in a virtual shopping task and lacked a cognitive strategy in planning compared to controls.

\subsection{Summary}

This section reflects the importance of social media, browsing and videos for online interactivity. A trend that can be seen is the rise of social media and how it is having an impact with video content especially as users are increasingly generating their own content on these sites. As multi-sensory online environments and virtual reality shopping environments are in their developing stages, it makes sense to incorporate online interactive elements. Increasing interactivity can also keep customers engaged, this is discussed in detail below.

\section{Engagement}

\subsection{Introduction}

Engagement has been commonly used in psychology, marketing, sociology, political science, organisational behaviour and education (Goodman 2012, Csikszentmihalyi 1997, Achterberg et al., 2003, Resnick 2001, Saks 2006). The definition of engagement seems to vary to different academics, some focus on the psychological aspects of engagement whilst others stress a behavioural focus. Brodie et al., (2011, p. 260) define this as a "psychological state which occurs by virtue of interactive, cocreative experiences with a focal agent (brand)...ultimately leading to loyalty" (Dessart et al., 2016, Brodie et al., 2011). Brodie et al (2011) in their working definition suggests that consumer engagement is a multi-dimensional concept consisting of cognitive, behavioural and emotional dimensions. In neuroscience, Berka et al (2007) suggests that engagement reflects information gathering, visual attention and attention allocation. Other scholars characterise user engagement as a subset of 'flow' (mentioned in more detail below) but in a more passive state, as user control, attention, curiosity and intrinsic interest is absent in this construct (Chapman et al., 1999).

In contrast to these common factors contributing to what engagement is, some definitions neglect the importance of motivation. Burns \& Fairclough (2015) define engagement as a psychological state in which intrinsic motivation causes selective attention at a psychological level, engagement has been operationalised through indicators of attentional and emotional processes, often overlooking motivational factors (Arapakis et al., 2014). In marketing, there are varying definitions to consumer engagement, however, these definitions are focused mainly on brand relationship rather than focus on the consumer (Mollen \& Wilson 2010, Hollebeek et al., 2011, Brodie et al., 2013). Also, little attention is given to consumer engagement as a psychological, cognitive and interactive component to consumer behaviour (Bowden 
et al., 2009, Brodie et al., 2013, Patterson et al., 2013). This section describes marketing theories of consumer engagement, categorising them into cognitive, emotional and behavioural components. Engagement is then displayed and categorised into other forms such as involvement, flow, participation etc.

\subsection{Measuring engagement via CE theory}

The origins of CE stems was discovered three decades ago in Norway (Gronroos 2010, Gummesson 1994). Since then, recent developments of CE were rooted in "service-dominant (S-D) logic" which views CE in the light of relationship marketing (RM) to create, sustain and enhance close relationships with their consumers (Mende et al., 2013, Vargo \& Lusch 2004, Vargo \& Lusch 2008). The actual term of “consumer/customer engagement" only transpired in the academic marketing in the last 5 years (Brodie et al., 2011).This section focuses on CE as a multi-dimensional concept. Where the majority of research scholars lends focus to CE as unidimensional either focusing on emotion (Catteeuw et al., (2007), Roberts \& Davenport (2002), cognition (Blumenfield \& Meece 1988, Guthrie \& Cox 2001) and behavioural (Balsano 2005, Saczynski et al., 2006) as constructs existing on their own only a handful of studies view emotional, cognitive and behavioural aspects of engagement occurring together, being multi-dimensional (Brodie et al., 2011, Macey \& Sneider 2008).

Figure 1 is adapted from Hollebeek et al., (2014) which visually depicts from their framework the multi-faceted nature of consumer engagement. Here we have just drawn out the cognitive, emotional and behavioural aspects of this.

CBE Antecedent

CBE

CBE Consequence

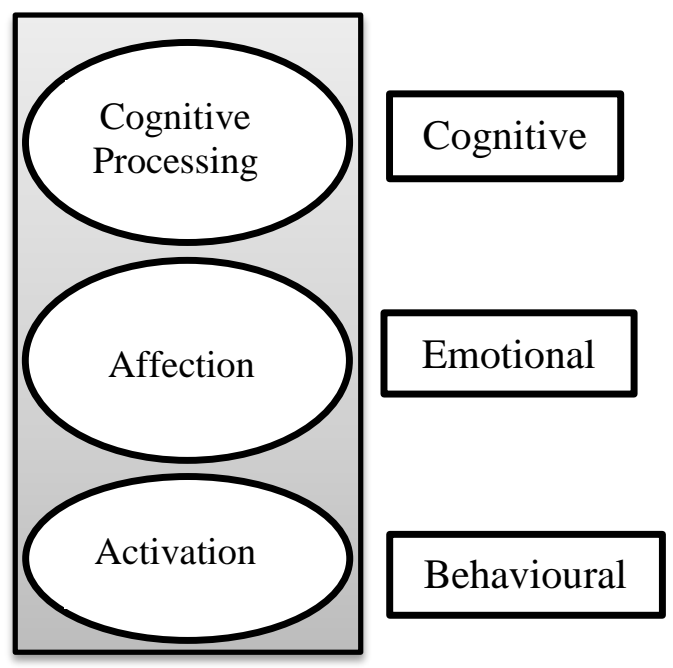

Figure 1. Adaptation of CBE Framework, Hollebeek et al., (2014) 
CE is suggested to extend beyond 'involvement' in that is not just the 'mere existence of cognition' is more interactive, experiential and adds value to the consumer (Brodie et al., 2011).Flow can be described as intrinsic enjoyment, loss of selfconsciousness and complete absorption to which an individual becomes extremely engrossed towards shopping online (Csikszentmihalyi 1988, Higgins 2006). Novak \& Hoffman (2003) found that increased flow creates greater expectations with future computer technology. Telepresence which is a milder version of flow to which the real and virtual world become blended is reported to be shaped by the media advertisements or videos (Javornik 2016). The concept of flow, overlaps with fluency theory in that although both involve low effort and high involvement, fluency contains ease of processing information or remembering something, which in turn puts the 'mind at ease' (Higgins 2006, Winkielman \& Cacioppo, 2001). Immersion as an engagement concept is now applied to the virtual world related to sensory experiences such as increasing screen size, sound quality, graphical fidelity or 3D screen capabilities.O' Brien \& Toms (2010) developed a scale to measure user engagement. In this scale there were ten attributes of engagement with some of the key attributes being aesthetics, focused attention, challenge, control, feedback, motivation, novelty and perceived time. Out of all of these outcome measures, focused attention was the highest attribute involved in engagement accounting for $29.73 \%$ of the sample.

Table 1: Types of consumer engagement and what they mean

\begin{tabular}{|c|c|c|c|}
\hline Construct & Originators & $\begin{array}{l}\text { Conceptual } \\
\text { Definition } \\
\end{array}$ & Dimension \\
\hline Flow & Csikzentmihalyi (1988). & $\begin{array}{l}\text { Individual's intrinsic } \\
\text { enjoyment, loss of self- } \\
\text { consciousness and complete } \\
\text { absorption towards } \\
\text { shopping online. }\end{array}$ & Cognition \\
\hline Focused Attention & Burke \& Leykin (2014) & $\begin{array}{l}\text { Attention acts as a filtering } \\
\text { mechanism but only one } \\
\text { activity utilised } \\
\text { concentration. }\end{array}$ & Cognition \\
\hline User Engagement & Obrien \& Toms (2010) & $\begin{array}{l}\text { This scale identifies } \\
\text { interactivity with flow, } \\
\text { play, focused attention, } \\
\text { perceived usability, } \\
\text { telepresence, satisfaction } \\
\text { and purchase intention. }\end{array}$ & Behavioural \\
\hline Involvement & Zaichowsky (1985) & $\begin{array}{l}\text { An individuals level of } \\
\text { interest }\end{array}$ & Behavioural \\
\hline Absorption & $\begin{array}{l}\text { Agarwal \& Karahanna } \\
\text { (2000) }\end{array}$ & $\begin{array}{l}\text { An intrinsic state that leads } \\
\text { to episodes of total attention }\end{array}$ & Behavioural \\
\hline Arousal & $\begin{array}{l}\text { Mehrabian \& Russell } \\
\text { (1973) }\end{array}$ & $\begin{array}{l}\text { Unitary emotional response } \\
\text { ranging from sleep to } \\
\text { frantic excitement }\end{array}$ & Emotion \\
\hline
\end{tabular}


The table above summarises the main types of consumer engagement. Involvement (Zaichowsky 1985) and flow (Csikzentmihalyi 1988) are the most reported subsets of engagement in marketing literature to date.

\subsection{Summary}

CE theories demonstrate that a multi dimensional approach to engagement, encompassing all cognitive, behavioural and emotional concepts provide a strong base of what engagement is rather than defining engagement as one-dimensional. From marketing literature, engagement has many forms and the most reported form is that of flow and involvement. However, these forms are not exhaustive, other forms such as telepresence or absorption are also an example of how complex engagement can be. Most of these forms of engagement were measured using likert or semantic differential scales on surveys. The section below looks at how engagement can be measured in the brain.

\section{EEG Engagement}

\subsection{Introduction}

This section flows differently to the above in that engagement theories are reviewed from neuroscientific and electrical engineering literature rather than just marketing literature. This paves way for a comparison of engagement from two different fields. Self-report measures of engagement rely on subject's awareness of their own mental processes which are often distorted by cognitive bias's such as demand characteristics or social desirability bias (Fedricks et al., 2004).Likewise other biometric tools such as heart rate variability or galvanic skin responses are more suited to measuring behaviour such as emotion or arousal rather than engagement, concluding EEG to be a sufficient tool to measure engagement.This section is divided up in looking at the parts of the brain associated with engagement rather than just defining engagement. Then studies looking specifically into engagement areas of the brain closely related to shopping or media is reported. It must be noted that limited neuroscientific literature report findings with engagement and online interactivity, this is where our novelty of the preliminary study in section 5 comes in.

\subsubsection{Anatomical Explanations of Engagement in the brain}

Engagement occurs mainly in the front of the brain otherwise known as the prefrontal cortex. The prefrontal cortex is believed to play a role in affective behaviour and judgement, lesions to this area result in impairment of executive functions such as decision making, organisation and planning (Afifi \& Bergman 2005). Neuro-imaging studies have shown higher engagement level processes to be associated in the frontal part of the brain involved in emotion and cognition and the temporal part of the brain involved in accessing memories with the general consensus being, the more engaged a consumer is, the more likely they are to draw from memories (Fugate 2007).

Davidson's model of motivation proposes that the brain is divided into both the approach (left side of brain) and withdrawal (right side of brain) (Davidson 1998). The levels of FAA (Frontal Alpha Asymmetry) is considered as a consistent index of approach activation (Engel \& Fries 2010, Schmeichel et al., 2010). 
from the brain in the frontal cortex between the left and right hemispheres of the brain (Briesemeister et al., 2013). Traditionally emotion is the common way of measuring consumer behaviour using the emotional valence system, however the FAA proves that information processing also a motivational component of engagement can be measured instead (Arapakis et al., 2017). As well as approach behaviours there are also withdrawal/avoidance behaviours (Davidson 1998).

With emotion recognition in the brain, a negative scenario would expect a negative emotion/ negative result. However, in the context of information interaction, people who consume both positive or negative information could be equally as engaged but engaged in a negative way (Arapakis et al., 2017). This therefore leads researchers to conclude that future research on user engagement should apply to an approach/avoidance model of motivation rather than the more commonly used bifactoral model of emotions (Arapakis et al., 2017). The brain default network lends support for activation when participants are not focused in tasks demanding attention which can constitute to disengagement or mind wandering/boredom (Greicius et al., 2003). A study looking at neural engagement during social approach motivation provides evidence in the brain via fMRI scanning to approach-avoidance paradigms connected towards a motivational component for engagement (Wu et al., 2015). The nucleus accubens (NAcc) is a key node in the brain related to reward processing and this triggers approach behaviour (Knutson \& Cooper 2005). The behavioural activation system (BAS) in the brain is an area that generates positive affect resulting in approach behaviour (Kennis et al., 2013, Wu et al., 2015).

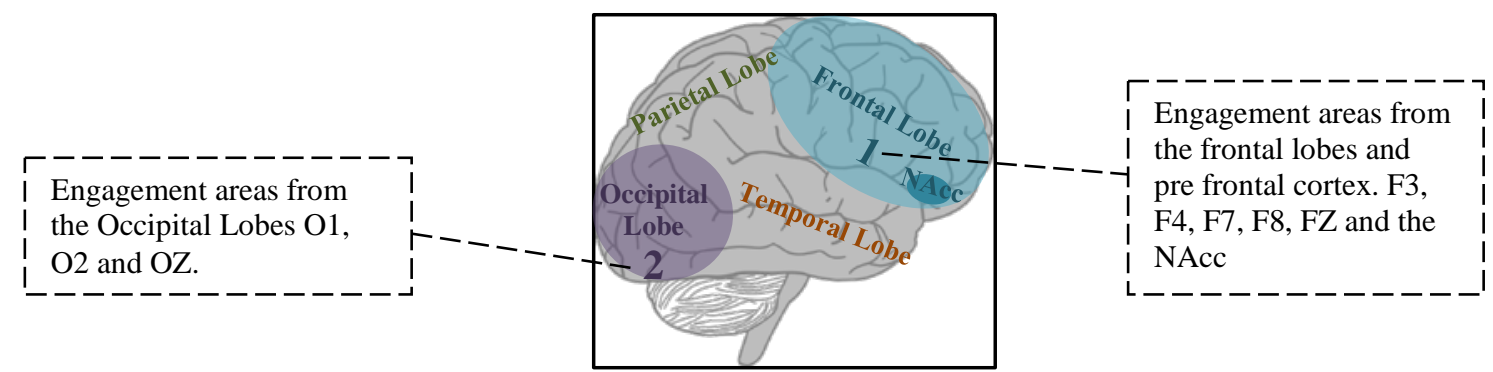

Figure 2. Brain locations of engagement

The above image (Fig 2.) summarises from the relevant literature cited above which parts of the brain is associated with engagement. From the diagram it is clear that mainly the front and back part of the brain is activated when looking at interactive media.

\subsubsection{Measuring Engagement with EEG}

An EEG is a technique for recording and analysing electrical activity of the brain. In order to record signals adequately, electrodes are placed in pairs on the scalp to which each pair transmits a signal to of of several recording channels of the EEG. The signal has a difference in voltage between the pair. The rhythmic fluctuation of this potential 
difference is depicted as oscillations on a line graph (Fine 2008). These oscillations measures frequencies of electrical currents to which are represented by waves and their length each given the name of a Greek letter (Casson et al. 2010, Cohen 2014).

- Delta: Activity at less than $4 \mathrm{~Hz}$.

- Theta: Activity between 4 and $8 \mathrm{~Hz}$.

- Alpha: Activity between 8 and $13 \mathrm{~Hz}$.

- Beta: Activity between 13 and $30 \mathrm{~Hz}$.

- Gamma: Activity over $30 \mathrm{~Hz}$.

Electrode positions are determined using 10-20 system which are named distances between electrodes (Casson 2010).

\begin{abstract}
Measuring consumer engagement through self-reported measures or through observation doesn't facilitate the focus of a shorter temporal scope in real time to track an engaged task through physiological metrics. Self-report measures rely on subject's awareness of their own mental processes which are often distorted by cognitive bias's such as demand characteristics or social desirability bias (Fedricks e al., 2004). Thus objectively Measuring engagement with EEG provides the insight into cognitive/emotional processes (Martinez- Penaranda et al., 2013). Measuring computer-mediated media (such as watching videos on YouTube), is more passive and therefore suggested to be measured via electrophysiological techniques (Arapakis et al 2017).Previous studies measuring engagement via EEG with passive media (TV adverts, social media channels etc.) have limited operationalisation of user engagement. For example, audiovisual media providing sensory information through images and sounds can also have physical attributes such as homepage visuals, attractive characters etc. that elicits automatic and emotional responses that is rarely measured (IIlan et al., 2004).
\end{abstract}

A study measuring mental workload in online shopping comparing Augmented Reality (AR) and Virtual Reality (VR) found that males have a higher mental workload for expensive products in VR than females (Zhao et al., 2017). Studies of left-brain activity demonstrates how complete absorption when shopping online even with limitations of online interfaces, consumers are so intrinsically involved with this experience that they do not seem to care about external factors around them (Demangeot \& Broderick 2007). The term engagement can also represent the eagerness to fulfil a goal (Parsons et al., 2015). However, little research has been conducted using an EEG for consumer engagement and brain behaviour relationships (Fugate 2007). Neuro-imaging studies have shown higher engagement level processes to be associated in the frontal part of the brain involved in emotion and cognition and
the temporal part of the brain involved in accessing memories with the general
consensus being, the more engaged a consumer is, the more likely they are to draw from memories (Fugate 2007). Few studies, although not wholly grounded in marketing theory, have investigated the positive relationships with consumer engagement concepts such as flow, novelty and enjoyment using an EEG (Wang and Hsu 2014, Leger et al., 2014, Yilmaz et al., 2014).An EEG study exemplifying the importance of a two-way interaction between biology and our social environment,
with mind as a concept for understanding the bidirectional influence between brain
and behaviour (Howard-Jones et al., 2015). There is a body of research that examines 
EEG responses to like/dislike analysis without considering a holistic perspective of consumer behaviour (Yilmaz et al. 2014) One study looks at high emotional value anc low emotional value of luxury products when alone and then when in a group. Using importance of a multidimensional view to engagement, incorporating emotion, cognition and behavioural aspects (Brodie et al., 2011). Romano's pyramid of engagement complements this by providing a physiological explanation for this. Attention is used first to choose important information, eliminating unnecessary stimuli. Emotion then produces physiological changes in the body such as changes in heart rate, respiration, muscle tone and temperature. Then action regulator occurs before an action takes place and attends to automatic mechanisms deciding what to store into memory and transform into actions, this all happens the frontal lobe (Romano 2013). Too much or too little information of causes boredom and disengagement and in turn avoidance (Parsons et al., 2015). Below is a table summarising all the studies associated with EEG engagement and shopping, media and

online interactive environments. 
Table 2. Derivatives of EEG engagement

\begin{tabular}{|c|c|c|c|c|c|}
\hline Author & $\begin{array}{l}\text { Type of } \\
\text { Engagement }\end{array}$ & Algorithm & $\begin{array}{l}\text { EEG } \\
\text { Device }\end{array}$ & Brain locations & Explanation \\
\hline $\begin{array}{l}\text { Rabbi et } \\
\text { al., } \\
\text { (2012) }\end{array}$ & Task Engagement & Beta/ (Alpha+Theta) & $\begin{array}{l}\text { B-Alert } \\
\text { wireless } \\
\text { sensor } \\
\text { headset }\end{array}$ & $\begin{array}{l}\text { Increased Beta activity } \\
\text { when wearing the space } \\
\text { suit in frontal locations. }\end{array}$ & $\begin{array}{l}\text { EEG changes were quantified and compared with direct responses of } \\
\text { participants partaking different tasks. B-Alert/ AMP (Attention, } \\
\text { memory, Profiler) software was used as part of the EEG wireless } \\
\text { acquisition system. }\end{array}$ \\
\hline $\begin{array}{l}\text { Szafir \& } \\
\text { Mutlu } \\
(2012)\end{array}$ & $\begin{array}{l}\text { Attention in } \\
\text { designing } \\
\text { adaptive agents }\end{array}$ & Beta/ (Alpha + Theta) & Neurosky & - & $\begin{array}{l}\text { Engagement levels measured in } 30 \text { second timeframes using two-way } \\
\text { repeated measures ANOVA. }\end{array}$ \\
\hline $\begin{array}{l}\text { Tacchino } \\
\text { et al., } \\
\text { (2016) }\end{array}$ & $\begin{array}{l}\text { Active } \\
\text { participation } \\
\text { during } \\
\text { movements }\end{array}$ & ERSP maps & - & $\begin{array}{l}\text { Mu and beta } \\
\text { frequencies in C3 } \\
\text { region }\end{array}$ & $\begin{array}{l}\text { Beta and MU frequency bands showed reactivity to movement } \\
\text { excecution.Mu frequency bands for active or passive tasks were } \\
\text { statistically significant from the baseline. }\end{array}$ \\
\hline $\begin{array}{l}\text { Freeman } \\
\text { et al } \\
\text { (1999) }\end{array}$ & $\begin{array}{l}\text { Adaptive } \\
\text { automation with a } \\
\text { visual tracking } \\
\text { task }\end{array}$ & Beta/ (Alpha + Theta) & $\begin{array}{l}\text { BIOPAC } \\
\text { EEF100A }\end{array}$ & $\begin{array}{l}\text { Measured in CZ, PZ, P3 } \\
\text { and P4 }\end{array}$ & $\begin{array}{l}200 \text { samples per second.1/theta out of the three engagement indexes } \\
\text { yielded the highest level of engagement. }\end{array}$ \\
\hline $\begin{array}{l}\text { Pope et } \\
\text { al., } \\
\text { (1995) }\end{array}$ & - & Beta/ (Alpha + Theta) & - & $\begin{array}{l}\text { EEG was recorded at } \\
\text { sites CZ, T5, F3, FZ, } \\
\text { F4, O1 and O2 }\end{array}$ & $\begin{array}{l}\text { Closed loop method enables an index of engagement to be identified } \\
\text { which is maximally sensitive to changes in task demand }\end{array}$ \\
\hline $\begin{array}{l}\text { Arapakis } \\
\text { et al., } \\
\text { (2017) }\end{array}$ & $\begin{array}{l}\text { Engagement in } \\
\text { online news } \\
\text { reading }\end{array}$ & $\begin{array}{l}\text { Frontal Alpha Asymmetry } \\
\text { (FAA). Frontal alpha in left } \\
\text { hemisphere and Prefrontal } \\
\text { alpha in right hemisphere. }\end{array}$ & Emotiv & $\begin{array}{l}\text { Left (FC3, F3 \& F7), } \\
\text { Right (FC4, F4, F8). }\end{array}$ & $\begin{array}{l}\text { EEG as well as Entrophy analysis reveals that there is a motivational } \\
\text { component of emotion associated with engagement. In a negative } \\
\text { scenario, a negative emotion would evoke behavioural avoidance. }\end{array}$ \\
\hline $\begin{array}{l}\text { Mc } \\
\text { Mahan } \\
\text { (2015) }\end{array}$ & $\begin{array}{l}\text { Engagement in } \\
\text { Gaming }\end{array}$ & $\begin{array}{l}\text { Frontal Theta } \\
\text { Frontal Theta/Parietal Alpha } \\
\text { Beta/ (Alpha + Theta) }\end{array}$ & Emotiv & $\begin{array}{l}\text { Measured in AF3, AF4, } \\
\text { F3, F4, F7, F8, FC5 \& } \\
\text { FC6 }\end{array}$ & $\begin{array}{l}\text { Engagement levels increased during death events compared to } \\
\text { general game play events using this index }\end{array}$ \\
\hline
\end{tabular}


The table above displays a detailed review of engagement and how they are measured with an EEG. Engagement is measured on different locations of the brain with corresponding algorithms. For instance, Pope et al., (1995) looks at the temporal, frontal and occipital lobes and measures engagement using the algorithm Beta/ (Alpha + Theta). Mcmahan (2015), Pope et al., (1995) Freeman et al., (1999) and Rabbi et al., (2012) commonly use the algorithm Beta/ (Alpha + Theta) to measure engagement which demonstrates a good chance of reliability if using these in future work. From the the table above, Mc Mahan (2015), Pope et al., (1995) and Arapakis et al., (2017). are the most suited papers of measuring engagement to via EEG for our study. The reason for this is due to the study using media to measure engagement are very closely matched to the CE engagement constructs stated above in section 3. However between these three studies different measurements are obtained thus a careful decision needs to be made when choosing an algorithm to measure engagement.

\subsection{Summary}

This section concludes EEG engagement measurement. In section 3, CE engagement was measured using scales on surveys, with EEG, engagement is measured using algorithms at different sites on the head. Section 3 reported flow and involvement to be popular forms of engagement whereas this section demonstrates how the front and back part of the brain with algorithm Beta/ (Alpha + Theta) is popular when measuring engagement in the brain.

\section{Preliminary Study}

\subsection{Introduction}

Adding all of the information from sections 1,3 and 4 constitutes to a design and a few results of a preliminary study. The main aim is to explore the impact of consumer engagement on interactive features in online fashion shopping environments (Social media, browsing and video's) measuring brain responses. The study has been designed to collect responses with female millennial consumers only 10 initial participants were analysed. Purposive sampling was used involving participants that are available to the researcher (Bryman 2011). Female fashion consumers who shop online were be investigated (Mintel 2014). ASOS.com was the website under investigation.

The study involved the participant visiting ASOS Instagram, looking at images only, interacting in likes, follows and sharing. Then the participant searches for a 'Jacket' via ASOS website. Finally the participant watches the catwalk video of their preferred jacket. The idea is to see out of the three levels of interactivity, which engages a consumer, the most or at which level of engagement (See Fig 1). 


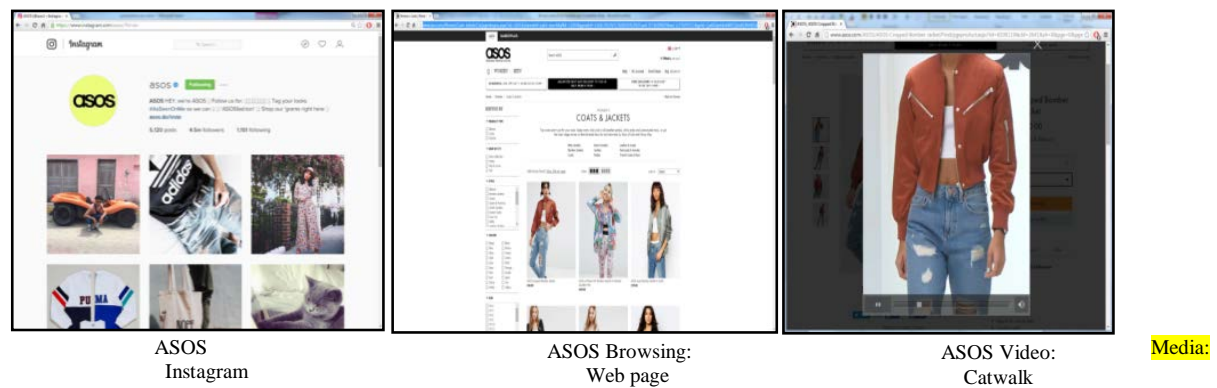

Fig 3 ASOS Instagram, Browsing and Catwalk Stimuli

The image below; Fig 4. Demonstrates how this experiment was set up on participants

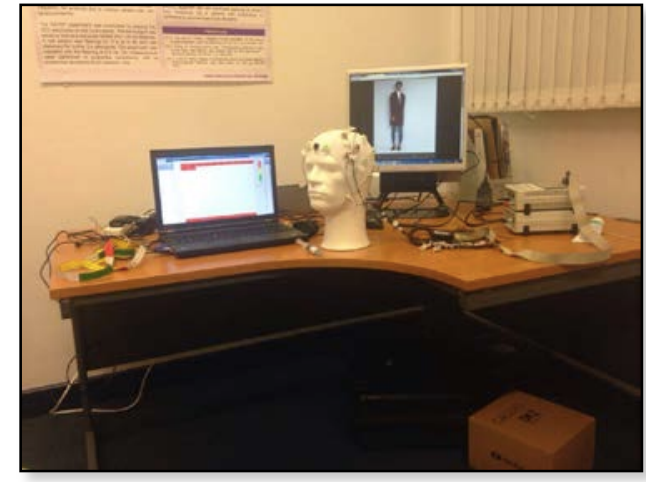

Fig 4 Experiment setup

The experiment measured 12 sites of engagement on the scalp.

A high quality EEG traditionally used for medical conditions is used due to its high quality data signals. The device is called the actiCHamp housing up to 160 channels and has the highest sampling frequency of $100 \mathrm{KHz}$. Oscillatory patterns of activity in the EEG range from and widths (alpha, beta, theta, delta and gamma) (Ohme \& Matukin 2012). Engagement algorithms Beta / Alpha + Theta on all locations, Theta/Alpha on frontal midline and parietal and Theta on frontal locations measured engagement in the brain.

\subsection{Findings}

Pilots consisted of 10 EEG results. EEG analysis was conducted in MatLab and twoway ANOVA was generated as a parametric test to see a difference between the 3 stimuli (social media, browsing and videos: Instagram and Youtube).

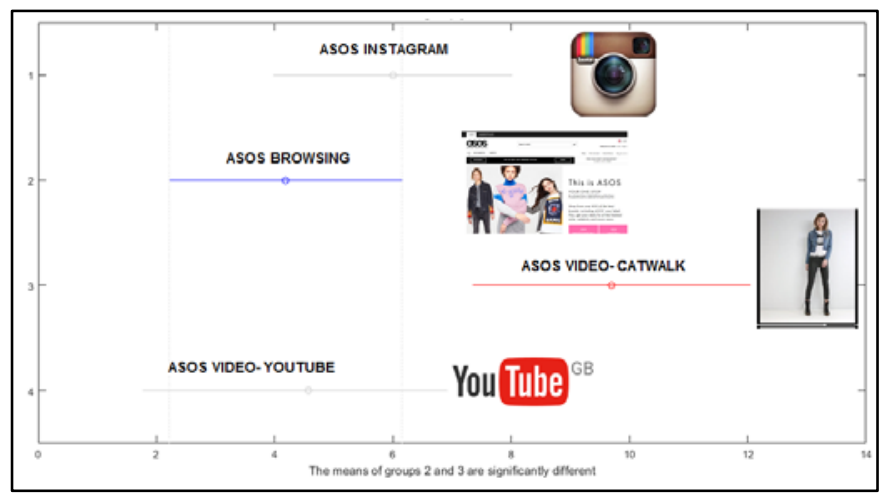


Fig. 5. Initial findings of 10 participants

ANOVA provides a statistical test of whether or not the means of several groups are equal, and therefore generalizes the t-test to more than two groups. ANOVAs are useful for comparing (testing) three or more means (groups or variables) for statistical significance. A significant result was found between catwalk and browsing. The ANOVA reveals higher engagement for browsing than watching the vide catwalk at real time. (Lower level of theta activity proves to be a higher level of engagement). However, there are many factors to consider as only first 10 participants were used so it is not a significant sample size. Also focusing on one retailer (ASOS.com) doesn't mean each level of interactivity is engaging or not engaging.

\subsection{Summary}

The preliminary study is very basic and is mentioned to demonstrate how online interactivity can be measured from the engagement concepts that are reported above. Although results are by no means conclusive, it does show that EEG engagement can be measured providing significant results when looking at different interactivity online.

\section{Conclusion}

From the literature presented above, three levels of interactivity virtual social presence, virtual theatrics and virtual atmospherics prove to be relevant in today's generation and therefore useful in measuring consumer responses. Engagement has been looked at by two perspectives, marketing and neuroscience which hasn't been viewed in this way before. It can be seen that engagement is difficult to measure for both disciplines. The review provides evidence that there are techniques that enable engagement to be measured in marketing via surveys using likert and semantic differential scales. In neuroscience engagement can be measured by looking at the front and back of the brain and algorithms using electrical bandwidths alpha, beta and theta can be used. The preliminary study proved that the concept using EEG for measuring engagement to online interactive aspects of ASOS worked and a significant difference between browsing and catwalks was found. Fashion retailers are actively searching for the latest technology innovations that can improve the shopping experience. John Lewis for example is using a company called JLAB to use Instagram as a social checkout by allowing consumers to buy products through its Instagram feed (Mintel 2016b). This shows how pivitol social media, browsing and videos are when it comes to future technological developments for retail. In the case 
of AR and VR shopping environments for the future, It is likely that more pure-play retailers will utilise real world retail spaces to support their virtual stores (Euromonitor International 2011). VR shopping environments at this stage are only in their developing stages, thus the need for a VR retail environment is a consideration for the future. "The biggest challenge is not only how expensive it is to produce content but how difficult it is to produce truly engaging content. There's a big learning curve” (Euromonitor 2016).

\section{References}

Achterberg, W., Pot, A. M., Kerkstra, A., Ooms, M., Muller, M., \& Ribbe, M. (2003). The effect of depression on social engagement in newly admitted Dutch nursing home residents. The Gerontologist, 43(2): 213-218.

Afifi, A, K. \& Bergman, R, A. (2005) Functional Neuroanatomy. McGraw-Hill, 3-416.

Agarwal, R., \& Karahanna, E. (2000). Time flies when you're having fun: Cognitive absorption and beliefs about information technology usage. MIS quarterly, 665-694.

Arapakis, I., Barreda-Angeles, M., \& Pereda-Banos, A. (2017). Interest as a Proxy of Engagement in News Reading: Spectral and Entropy Analyses of EEG Activity Patterns. IEEE Transactions on Affective Computing.

Balsano, A. B. (2005). Youth civic engagement in the United States: Understanding and addressing the impact of social impediments on positive youth and community development. Applied Developmental Science, 9(4):188-201.

Bargh, J. A., \& Pietromonaco, P.(1982). Automatic information processing and social perception: The influence of trait information presented outside of conscious awareness on impression formation. Journal of personality and Social psychology, 43(3): 437.

Barnes, S, J., Mattsson, J. \& Hartley, N. (2015). Assessing the value of real-life brands in Virtual Worlds, Technological Forecasting \& Social Change, 92, 12-24.

Barnes, S, J.\& Mattsson, J. (2008). Brand value in virtual worlds: an axiological approach. Journal of Electronic commerce Research, 6(1): 195-206.

Bart, Y., Shankar, V., Sultan, F., \& Urban, G. L. (2005). Are the drivers and role of online trust the same for all web sites and consumers? A large-scale exploratory empirical study. Journal of marketing, 69(4):133-152.

Berka, C., Levendowski, D. J., Lumicao, M. N., Yau, A., Davis, G., Zivkovic. \& Craven, P. L. (2007). EEG correlates of task engagement and mental workload in vigilance, learning, and memory tasks. Aviation, space, and environmental medicine, 78(5): B231-B244.

Bischof, W. F., \& Boulanger, P. (2003). Spatial navigation in virtual reality environments: an EEG analysis. CyberPsychology \& Behavior, 6(5): 487-495.

Briesemeister, B. B., Tamm, S., Heine, A., \& Jacobs, A. M. (2013). Approach the good, withdraw from the bad-a review on frontal alpha asymmetry measures in applied psychological research. Psychology, 4(03): 261.

Brodie, R. J., Hollebeek, L. D., Juric, B., \& Ilic, A. (2011). Customer engagement: conceptual domain, fundamental propositions, and implications for research. Journal of Service Research, 1-20.

Brodie, R. J., Ilic, A., Juric, B. \& Hollebeek, L. (2013). Customer Engagement in A Virtual Brand Community: An exploratory Analysis. Journal of Business Research, 66(1):105144.

Bryman, A. (2011). Research methods in the study of leadership. The SAGE handbook of leadership, 15-28.

Burke, R. R., \& Leykin, A. (2014). Identifying the Drivers of Shopper Attention, Engagement, and Purchase. In Shopper Marketing and the Role of In-Store Marketing,147-187. 
Casson A, Yates D, Smith S, Duncan J, Rodriguez-Villegas E. (2010). Wearable electroencephalography. Engineering in Medicine and Biology Magazine, IEEE.Vol, 29(3): 44-56.

Catteeuw, F., Flynn, E., \& Vonderhorst, J. (2007). Employee engagement: Boosting productivity in turbulent times. Organization Development Journal,25(2): P151.

Cohen, M, X. (2014). Analysing Neutral Time Series Data: Theory and Practice, MIT Press: Cambridge, Massachusetts, London.

Csikszentmihalyi, M. (1997). Finding flow: The psychology of engagement with everyday life. Basic Books.

Dailey, L. (2004). Navigational web atmospherics: Explaining the influence of restrictive navigation cues. Journal of Business Research, 57(7): 795-803.

Davidson, R. J. (1998). Anterior electrophysiological asymmetries, emotion, and depression: Conceptual and methodological conundrums. Psychophysiology, 35(5): 607-614.

Deloitte Global (2017). Global Predictions 2017 [online] Available at s://www2.deloitte.com/global/en/pages/technology-media-andtelecommunications/articles/tmt-predictions.html [Accessed March 2017].

Demangeot, C. \& Broderick, A.J. (2007). Conceptualising consumer behavior in online shopping environments, International Journal of Retail \& Distribution Management, 35(11): 878-894.

Dessart, L., Veloutsou, C., \& Morgan-Thomas, A. (2016). Capturing consumer engagement: duality, dimensionality and measurement. Journal of Marketing Management, 32(5-6): 399-426.

Engel, A. K., \& Fries, P. (2010). Beta-band oscillations-signalling the status quo?. Current opinion in neurobiology, 20(2):156-165.

Euromonitor International (2011). Virtual Retailers Entering the Real World: New Store-Based Concepts From Pure-Play Internet Retailers [online] Available at http://blog.euromonitor.com/2011/11/virtual-retailers-entering-the-real-world-newstore-based-concepts-from-pure-play-internet-retailers.html [Accessed 24th April 2017].

Euromonitor International (2014). What's New with the Emerging Market Consumer? [online] Available at https://www.portal.euromonitor.com/portal/analysis/blogindex [Accessed 15 October 2015].

Euromonitor International (2016). Virtual Reality: A Game Changer for Luxury Retail [online] Available at http://www.portal.euromonitor.com/portal/analysis/tab [Accessed March 2016].

Fine, C. (2008). The Britanica Guide To The Brain. Running Press Book Publishers, 3-338.

Fiore, S, G. \& Kelly, S. (2007). Surveying the use of sound in online stores: Practices, possibilities and pitfalls for user experience, International Journal of Retail \& Distribution Management, 35(7): 600-611.

Foxall, G.R., Oliveira-Castro, J.M. \& Schrezenmaier, T.C. (2004). The Behavioural Economics of Consumer Brand Choice: Patterns of Reinforcement and Utility Maximisation, Behavioral Processes, 66(3): 235-260.

Fredricks, J. A., Blumenfeld, P. C., \& Paris, A. H. (2004). School engagement: Potential of the concept, state of the evidence. Review of educational research, 74(1): 59-109.

Freeman, F. G., Mikulka, P. J., Prinzel, L. J., \& Scerbo, M. W. (1999). Evaluation of an adaptive automation system using three EEG indices with a visual tracking task. Biological psychology, 50(1): 61-76.

Fugate, D. L. (2007). Neuromarketing: a layman's look at neuroscience and its potential application to marketing practice. Journal of Consumer Marketing, 24(7): 385-394.

Gearhart, S., \& Zhang, W. (2014). Gay bullying and online opinion expression: Testing spiral of silence in the social media environment. Social science computer review, 32(1): 1836.

Gilovich, T., \& Kumar, A. (2015). Chapter Four-We'll Always Have Paris: The Hedonic Payoff from Experiential and Material Investments. Advances in experimental social psychology, 51: 147-187. 
Gorn, G. J., Chattopadhyay, A., Sengupta, J., \& Tripathi, S. (2004). Waiting for the web: how screen color affects time perception. Journal of marketing research, 41(2): 215-225.

Greicius, M. D., Krasnow, B., Reiss, A. L., \& Menon, V. (2003). Functional connectivity in the resting brain: a network analysis of the default mode hypothesis. Proceedings of the National Academy of Sciences, 100(1): 253-258.

Guthrie, J. T., \& Cox, K. E. (2001). Classroom conditions for motivation and engagement in reading. Educational psychology review, 13(3): 283-302.

Ha, Y., Kwon, W. S., \& Lennon, S. J. (2007). Online visual merchandising (VMD) of apparel web sites. Journal of Fashion Marketing and Management, 11(4): 477-493.

Harnish, R. J., \& Bridges, K. R. (2016). Mall Haul Videos: Self-Presentational Motives and the Role of Self-Monitoring. Psychology \& Marketing, 33(2): 113-124.

Häubl, G., \& Trifts, V. (2000). Consumer decision making in online shopping environments: The effects of interactive decision aids. Marketing science,19(1): 4-21.

Hennig-Thurau, T., Gwinner, K. P., Walsh, G., \& Gremler, D. D. (2004). Electronic word-ofmouth via consumer-opinion platforms: What motivates consumers to articulate themselves on the Internet?. Journal of interactive marketing, 18(1): 38-52.

Higgins, E. T. (2006). Value from hedonic experience and engagement.Psychological review, 113(3): 439.

Hoch, S. J., \& Deighton, J. (1989). Managing what consumers learn from experience. The Journal of Marketing, 1-20.

Hollebeek, L. D., Glynn, M. S., \& Brodie, R. J. (2014). Consumer brand engagement in social media: Conceptualization, scale development and validation. Journal of interactive marketing, 28(2):149-165.

Howard-Jones, P., Ott, M., van Leeuwen, T., \& De Smedt, B. (2015). The potential relevance of cognitive neuroscience for the development and use of technology-enhanced learning. Learning, media and technology, 40(2): 131-151.

Hsiao, K. L., Chuan-Chuan Lin, J., Wang, X. Y., Lu, H. P., \& Yu, H. (2010). Antecedents and consequences of trust in online product recommendations: An empirical study in social shopping. Online Information Review, 34(6): 935-953.

Ilan, A. B., Smith, M. E., \& Gevins, A. (2004). Effects of marijuana on neurophysiological signals of working and episodic memory. Psychopharmacology, 176(2): 214-222.

Javornik, A. (2016). Augmented reality: Research agenda for studying the impact of its media characteristics on consumer behaviour. Journal of Retailing and Consumer Services, 30, 252-261.

Jiang, Z., \& Benbasat, I. (2007). The effects of presentation formats and task complexity on online consumers' product understanding. MIS Quarterly, 475-500.

Jung, Y., \& Pawlowski, S. D. (2014). Understanding consumption in social virtual worlds: A sensemaking perspective on the consumption of virtual goods. Journal of Business Research, 67(10): 2231-2238.

Kawaf, F., \& Tagg, S. (2017). The construction of online shopping experience: A repertory grid approach. Computers in Human Behavior, 72: 222-232.

Kahneman, D. (1973). Attention and effort (p. 246). Englewood Cliffs, NJ: Prentice-Hall.

Kennis, M., Rademaker, A. R., \& Geuze, E. (2013). Neural correlates of personality: an integrative review. Neuroscience \& Biobehavioral Reviews,37(1):73-95.

Kiesler, S., \& Sproull, L. (1992). Group decision making and communication technology. Organizational behavior and human decision processes, 52(1): 96-123.

King, D. L., Delfabbro, P. H., Kaptsis, D., \& Zwaans, T. (2014). Adolescent simulated gambling via digital and social media: An emerging problem. Computers in Human Behavior, 31, 305-313.

Kircher, T. T., Senior, C., Phillips, M. L., Benson, P. J., Bullmore, E. T., Brammer, M. \& David, A. S. (2000). Towards a functional neuroanatomy of self processing: effects of faces and words. Cognitive Brain Research,10(1): 133-144.

Kleinschmit, M., Reid, A., \& Rizzo, R. (2012). Virtual Future: real Life or Fantasy. Esomar, 116. 
Kluge, P. N., Königsfeld, J. A., Fassnacht, M., \& Mitschke, F. (2013). Luxury web atmospherics: an examination of homepage design. International Journal of Retail \& Distribution Management, 41(11/12): 901-916.

Knutson, B., \& Cooper, J. C. (2005). Functional magnetic resonance imaging of reward prediction. Current opinion in neurology, 18(4): 411-417.

Kotler, P. (1973). Atmospherics as a marketing tool. Journal of retailing, 49(4): 48-64.

Koo, D. M., \& Ju, S. H. (2010). The interactional effects of atmospherics and perceptual curiosity on emotions and online shopping intention. Computers in Human Behavior,

KPMG (2017). The future of virtual and augmented reality: Digital disruption or disaster in the making? [online] Available at http://www.kpmgtechgrowth.co.uk/the-future-of-virtualand-augmented-reality-digital-disruption-or-disaster-in-the-making/[Accessed March 2017]

Lim, L., Hart, H., Mehta, M. A., Simmons, A., Mirza, K., \& Rubia, K. (2015). Neural correlates of error processing in young people with a history of severe childhood abuse: an fMRI study. American Journal of Psychiatry, 1-9.

Léger, P. M., Davis, F. D., Cronan, T. P., \& Perret, J. (2014). Neurophysiological correlates of cognitive absorption in an enactive training context. Computers in Human Behavior, 34: 273-283.

Macey, W. H., \& Schneider, B. (2008). Engaged in engagement: We are delighted we did it. Industrial and Organizational Psychology, 1(1): 76-83.

Mahoney, M. (2001). E-tailers dangle 3D imaging to covert surfers to buyers. E-commerce Times.

Manganari, E, E., Siokomos, G, J. \&Vrechopoulos, A, P. (2009). Store atmosphere in web retailing, European Journal of Marketing. 43 (9/10):1140-1153.

Manganari, E. E., Siomkos, G. J., Rigopoulou, I. D., \& Vrechopoulos, A. P. (2011). Virtual store layout effects on consumer behaviour: applying an environmental psychology approach in the online travel industry. Internet Research, 21(3): 326-346

Martinez-Peñaranda, C., Bailer, W., Barreda-Ángeles, M., Weiss, W., \& Pereda-Baños, A. (2013). A psychophysiological approach to the usability evaluation of a multi-view video browsing tool. In International Conference on Multimedia Modeling, 456-466

Mazursky, D., \& Vinitzky, G. (2005). Modifying consumer search processes in enhanced online interfaces. Journal of Business Research, 58(10): 1299-1309.

Mcmahan, T., Parberry, I., \& Parsons, T. D. (2015). Evaluating Electroencephalography Engagement Indices During Video Game Play.

Meece, J. L., Blumenfeld, P. C., \& Hoyle, R. H. (1988). Students' goal orientations and cognitive engagement in classroom activities. Journal of educational psychology, 80(4): 514.

Mehrabian, A., Russell, J, A. (1973). A Measure of Arousal Seeking Tendency, Environment and Behavior, 5(3): 315.

Mehta, R., Sharma, N. K., \& Swami, S. (2013). The impact of perceived crowding on consumers' store patronage intentions: Role of optimal stimulation level and shopping motivation. Journal of Marketing Management, 29(7-8): 812-835.

Mende, S., \& Roseman, D. (2013). The aligning forces for quality experience: Lessons on getting consumers involved in health care improvements. Health Affairs, 32(6): 10921100 .

Mintel (2016)a Fashion Online [online] Available at file://nask.man.ac.uk/home\$/Desktop/PhD\%20Reading/Market\%20Research/Fashion \%20Online\%20-\%20UK\%20-\%20August\%202014\%20-

\%20Executive\%20Summary.pdf[Accessed 7th November 2016].

Mintel (2016)b Fashion Online [online] Available at file:///G:/Paper\%202017\%20ARVR/Fashion\%20Technology\%20and\%20Innovation\%20-\%20UK\%20$\% 20$ September\%202016\%20-\%20Executive\%20Summary.pdf [Accessed $20^{\text {th }}$ April 2017]. 
Mollen, A., \& Wilson, H. (2010). Engagement, telepresence and interactivity in online consumer experience: Reconciling scholastic and managerial perspectives. Journal of business research, 63(9): 919-925.

Morandin, G., Bagozzi, R. P., \& Bergami, M. (2013). Brand community membership and the construction of meaning. Scandinavian Journal of Management, 29(2):173-183.

Murray, C. D., Fox, J., \& Pettifer, S. (2007). Absorption, dissociation, locus of control and presence in virtual reality. Computers in Human Behavior, 23(3):1347-1354.

Negut, A., Matu, S. A., Sava, F. A., \& David, D. (2016). Virtual reality measures in neuropsychological assessment: a meta-analytic review. The Clinical Neuropsychologist, 1-20.

Nielsen, J. (1999). Designing web usability: The practice of simplicity. New Riders Publishing.

Novak, T. P., Hoffman, D. L., \& Yung, Y. F. (2000). Measuring the customer experience in online environments: A structural modelling approach. Marketing science, 19(1): 2242.

O'Brien, H. L., \& Toms, E. G. (2010). The development and evaluation of a survey to measure user engagement. Journal of the American Society for Information Science and Technology, 61(1): 50-69

Ohme, R. \& Matukin, M. (2012). A Small Frog that Makes a Big Difference, IEEE Pusle, 2833

Okonkwo, U. (2010). Luxury online: Styles, systems, strategies. Palgrave Macmillan.

Peck, J., \& Childers, T. L. (2003). To have and to hold: The influence of haptic information on product judgments. Journal of Marketing, 67(2): 35-48.

Pope, A. T., Bogart, E. H., \& Bartolome, D. S. (1995). Biocybernetic system evaluates

indices of operator engagement in automated task. Biological psychology, 40(1): 187-

195.

Pozharliev, R., Verbeke, W. J., Van Strien, J. W., \& Bagozzi, R. P. (2015). Merely Being with You Increases My Attention to Luxury Products: Using EEG to Understand Consumers' Emotional Experience with Luxury Branded Products. Journal of Marketing Research, 52(4): 546-558.

Rabbi, A. F., \& Fazel-Rezai, R. (2012). A fuzzy logic system for seizure onset detection in intracranial EEG. Computational intelligence and neuroscience, 1-12.

Resnick, P. (2001).The social cost of cheap pseudonyms. Journal of Economics \& Management Strategy, 10(2): 173-199.

Roberts, D. R., \& Davenport, T. O. (2002). Job engagement: Why it's important and how to improve it. Employment Relations Today, 29(3): 21-29.

Robson, K., Plangger, K., Kietzmann, J. H., McCarthy, I., \& Pitt, L. (2015). Is it all a game?

Understanding the principles of gamification. Business Horizons, 58(4): 411-420.

Romano, J. (2013). The Neuropyramid. Bubok.

Saczynski, J. S., Pfeifer, L. A., Masaki, K., Korf, E. S., Laurin, D., White, L., \& Launer, L. J. (2006). The effect of social engagement on incident dementia the Honolulu-Asia aging study. American Journal of Epidemiology,163(5): 433-440.

Saks, A. M. (2006). Antecedents and consequences of employee engagement. Journal of managerial psychology, 21(7): 600-619.

Schmeichel, B. J., Harmon-Jones, C., \& Harmon-Jones, E. (2010). Exercising self-control increases approach motivation. Journal of personality and social psychology, 99(1): 162.

Skorupa, J. (2012) Shopper Experience Study, RIS news magazine.

Spence, C. \& Gallace (2011). Multisensory design: Reaching out to touch the consumer. Psychology \& Marketing, 28: 267-308.

Statista (2017). Retail sales of ASOS worldwide in financial year 2014 to 2016, by region (in 1,000 GBP) [online] Available at https://www.statista.com/statistics/500739/asos-retailsales-by-region-worldwide/ [Accessed March 2017].

Steckel, J. H., Winer, R. S., Bucklin, R. E., Dellaert, B. G., Drèze, X., Häubl, G. \& Rangaswamy, A. (2005). Choice in interactive environments. Marketing Letters, 16(3): 309-320. 
Szafir, D., \& Mutlu, B. (2012). Pay attention!: designing adaptive agents that monitor and improve user engagement. In Proceedings of the SIGCHI Conference on Human Factors in Computing Systems, 11-20

Tacchino, G., Gandolla, M., Coelli, S., Barbieri, R., Pedrocchi, A., \& Bianchi, A. M. (2016). EEG Analysis During Active and Assisted Repetitive Movements: Evidence for Differences in Neural Engagement. IEEE Transactions on Neural Systems and Rehabilitation Engineering.

Turk, M., \& Pentland, A. (1991). Eigenfaces for recognition. Journal of cognitive neuroscience, 3(1): 71-86.

Vargo, S. L., \& Lusch, R. F. (2004). Evolving to a new dominant logic for marketing. Journal of marketing, 68(1): 1-17.

Vargo, S. L., \& Lusch, R. F. (2008). Service-dominant logic: continuing the evolution. Journal of the Academy of marketing Science, 36(1): 1-10.

Wade Clarke, D., Perry, P., \& Denson, H. (2012). The sensory retail environment of small fashion boutiques. Journal of Fashion Marketing and Management, 16(4): 492-510.

Wang, Y. \& Hsu, C., (2011). Network Traces of Virtual Worlds : Measurements and Applications, in proceedings of the secondannual ACM conference on Multimedia Systems, 105-110

Wang, C. C., \& Hsu, M. C. (2014). An exploratory study using inexpensive electroencephalography (EEG) to understand flow experience in computer-based instruction. Information \& Management, 51(7): 912-923.

Webster, J., \& Ahuja, J. S. (2006). Enhancing the design of web navigation systems: The influence of user disorientation on engagement and performance. MIS Quarterly, 661678.

Winkielman, P., \& Cacioppo, J. T. (2001). Mind at ease puts a smile on the face: psychophysiological evidence that processing facilitation elicits positive affect. Journal of personality and social psychology, 81(6): 989

Wu, H. K., Lee, S. W. Y., Chang, H. Y., \& Liang, J. C. (2013). Current status, opportunities and challenges of augmented reality in education. Computers \& Education, 62, 41-49.

Wu, Z., Li, Y., \& Radke, R. J. (2015). Viewpoint invariant human re-identification in camera networks using pose priors and subject-discriminative features. IEEE Transactions on Pattern Analysis and Machine Intelligence, 37(5): 1095-1108.

Xu, Q., \& Sundar, S. S. (2014). Lights, camera, music, interaction! Interactive persuasion in ecommerce. Communication Research, 41(2): 282-308

Yılmaz, B., Korkmaz, S., Arslan, D. B., Güngör, E., \& Asyalı, M. H. (2014). Like/dislike analysis using EEG: determination of most discriminative channels and frequencies. Computer methods and programs in biomedicine,113(2): 705-713.

Yoo, C. W., Kim, Y. J., \& Sanders, G. L. (2015). The impact of interactivity of electronic word of mouth systems and E-Quality on decision support in the context of the emarketplace. Information \& Management, 52(4): 496-505.

Zaichkowsky, J. L. (1985). Measuring the involvement construct. Journal of consumer research, 12(3): 341-352.

Zhang, Y., Feick, L., \& Mittal, V. (2014). How males and females differ in their likelihood of transmitting negative word of mouth. Journal of Consumer Research, 40(6): 10971108.

Zhang, X., Li, S., Burke, R. R., \& Leykin, A. (2014). An examination of social influence on shopper behavior using video tracking data. Journal of Marketing, 78(5): 24-41.

Zhao, X., Shi, C., You, X., \& Zong, C. (2017). Analysis of Mental Workload in Online Shopping: Are Augmented and Virtual Reality Consistent?.Frontiers in Psychology, 8. 